\title{
Endless summer: internal loading processes dominate nutrient cycling in tropical lakes
}

\author{
PETER KILHAM and SUSAN SOLTAU KILHAM* Department of Biology and \\ Center for Great Lakes Aquatic Sciences, The University of Michigan, Ann Arbor, \\ Michigan, U.S.A., *Department of Biology, The University of Michigan, Ann Arbor, \\ Michigan, U.S.A.
}

SUMMARY. 1. Fossil diatom assemblages deposited in more than a dozen African lakes roughly 9500 years BP were dominated by a single planktonic species, Stephanodiscus astraea (Ehrenb.) Grun. (although realistically this is likely to be a species complex). These diatoms flourished when lake-levels were maximal. Data are included from many of the large African lakes, and others extending from Lake Abhé, Ethiopia, to Lake Cheshi, Zambia.

2. Because the ecological physiology of Stephanodiscus species is well known one can predict the nutrient regime that must have existed when Stephanodiscus bloomed. Owing to competition for resources Stephanodiscus species dominate when the supply ratio of silicon to phosphorus (in moles) in the epilimnion is relatively low ( $\mathrm{Si}: \mathrm{P} \sim 1)$. Consequently, lakes dominated by $S$. astraea are often hypereutrophic.

3. We propose a series of hypotheses to explain why tropical lakes have decreasing Si:P ratios as lake-levels increase, primarily owing to internal P-loading processes in the epilimnia. These observations appear to contradict present conceptions of the fundamental relationships governing nutrient loadings to and within lakes. Tropical lakes appear to have had increasing epilimnetic phosphorus loading as lake-levels increased. In contrast, large, deep lakes in the temperate zone are usually oligotrophic, with high Si:P ratios.

4. Our major conclusion is that regeneration rates are greater than removal rates for phosphorus in tropical lakes as compared to temperate lakes, especially where epilimnetic mixing exceeds $50 \mathrm{~m}$. Biological control of the elemental cycles dominate in tropical lakes, whereas nutrient cycles in temperate lakes are dominated by physical processes for a large part of the year. This results in major differences in the fundamental mechanisms of nutrient regeneration and their relationships to morphometric features of lakes in the two regions. 


\section{Introduction}

Diatoms are excellent indicators of the biogeochemical mileau in which they grow, but the interpretation of the palaeoecological significance of particular 'indicator' species is generally hampered by scanty knowledge of the mechanisms controlling their modern distributions. In this paper we will make use of ecophysiological knowledge about freshwater species in the genus Stephanodiscus to interpret fossil records from Africa and to suggest some generalizations about relative cycling rates of phosphorus and silicon in tropical lakes with respect to lake morphometry. The conclusions we will reach appear to violate one of the oldest 'laws' of limnology, namely that shallow lakes are more productive than deep ones (HuitfeldtKaas, 1898). Fee (1979, p. 414), has called this 'one of the few quantitatively well established biological generalities about lakes'.

Approximately 9500 years BP almost all of the lakes in intertropical Africa for which there are records were at a high lake level (Fig. 1). Large lakes have bigger areas and therefore deeper mixed layers (Kling, 1988). Remarkably, one genus of planktonic diatoms, Stephanodiscus, was dominant at this time (Gasse, 1980; Table 1). The ecophysiology of Stephanodiscus is such that members of this genus are characterized as

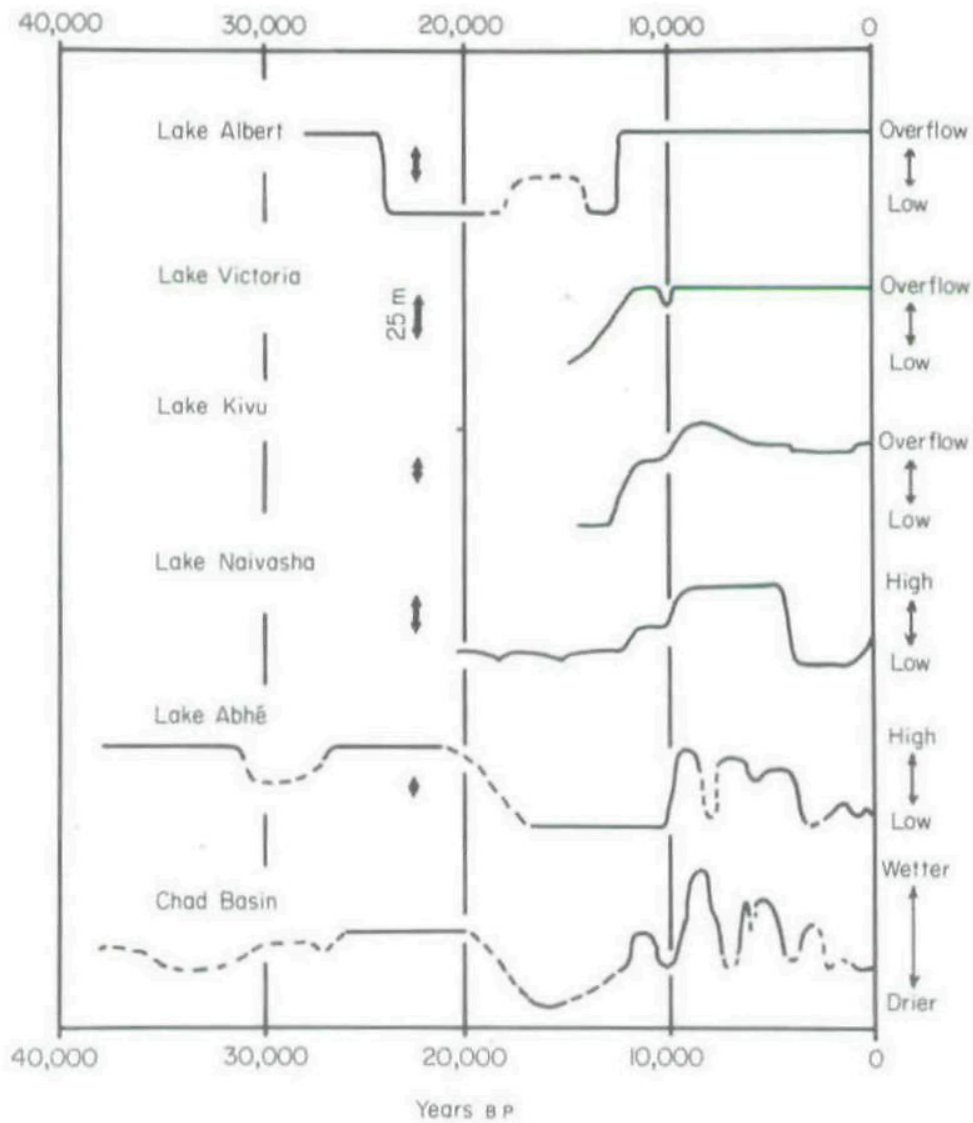

FIG. 1. Inferred water-level changes in several African lake basins. Data are from the following sources: Lake Albert: Harvey, 1976; Lake Victoria: Kendall, 1969; Lake Kivu: Hecky, 1978, and Haberyan \& Hecky, 1987; Lake Naivasha: Richardson \& Richardson, 1972, and Richardson \& Dussinger, 1986; Lake Abhè: Gasse, 1977, and Gasse, Rognon \& Street, 1980; Chad Basin: Servant \& Servant-Vildary, 1980. The curve for the Chad Basin shows relative variations in the rainfall to evaporation ratio as determined from palaeolimnological data. Lake basins from the top of the figure are ordered with respect to increasing responsiveness to climatic change. Dashed lines indicate water-level changes that are less well established. All scale-lengths represent a $25 \mathrm{~m}$ change in water-level. (Redrawn and modified from Hamilton, 1982.) 
TABLE 1. Lakes in East and Central Africa which were dominated by Stephanodiscus spp. when maximal lake-levels were attained at the beginning of the Holocene

\begin{tabular}{rllc}
\hline & Lake* & Reference & $\begin{array}{c}\text { Time }\left(\times 10^{3}\right) \\
\text { (years BP) }\end{array}$ \\
\hline$(1)$ & Abhé & Gasse, 1977 & $9.4-8.4$ \\
$(2)$ & Afrera & Gasse, 1980 & c. $9 ?$ \\
$(3)$ & Albert & Harvey, 1976 & $12.5-0$ \\
$(4)$ & Chad & Servant \& Servant, 1983 & $9.0-8$ \\
$(5)$ & Chishi & Stager, 1984b & $37.0-4$ \\
$(6)$ & Kivu & Haberyan \& Hecky, 1987 & $13.3-5$ \\
$(7)$ & Manyara & Holdship, 1976 & c. 10.0-8 \\
$(8)$ & Naivasha & Richardson \& Richardson, 1972 & $9.2-5.7$ \\
$(9)$ & Nakuru & Richardson \& Dussinger, 1986 & $10.0-4 ?$ \\
$(10)$ & Rukwa & Haberyan, 1987 & $12.7-4.4$ \\
$(11)$ & Tanganyika & Haberyan \& Hecky, 1987 & $15.9-9.9 ?$ \\
$(12)$ & Turkana & Owen et al., 1982 & $9.9-9.2 ?$ \\
$(13)$ & Victoria & Stager, 1984a & $16.0-0$ \\
$(14)$ & Ziway-Shala & Gasse \& Descourtieux, 1979 & c. $9.5-8$ \\
\hline
\end{tabular}

"Lake Elmenteita (Kenya) was an alkaline, saline lake between 29,300 and c. 8700 BP when lake-levels were low. Stephanodiscus rotula (Kütz.) Hendey (=S. astrae) was dominant from about $8500-7500 \mathrm{BP}$ and around $6500 \mathrm{BP}$ when lake-levels were higher (see Richardson \& Dussinger, 1986).

†Time interval including the period 10,000-8000 years BP.

growing best at low Si:P ratios (Kilham, 1984; Kilham, Kilham \& Hecky, 1986). This means that phosphorus loading to these lakes must have been quite high, creating a 'silica demand' (Kilham, 1971). This leads to dominance by diatom species that are superior competitors for silicon. Fig. 2 illustrates the Si:P tradeoff curve for growth relationships among planktonic species in African lakes (Fig. 2a; Kilham et al., 1986) and one example of modern distributions of these species in Lake Kivu (Fig. 2b). Lake Kivu has a range of Si:P ratios, from high in an isolated bay $(\mathrm{Si}: \mathrm{P}=420)$, to moderate in the main body of the lake $(\mathrm{Si}: \mathrm{P}=189)$, to very low in the southern bay of the lake ( $\mathrm{Si}: \mathrm{P}=1.45)$. The relative abundances of species in the three genera in the different regions of Lake Kivu are consistent with the Si:P growth requirements illustrated in Fig. 2(a).

Given that Stephanodiscus species are indicators of high $\mathrm{P}$ loading to the epilimnia of lakes (approaching eutrophic conditions), how was it possible for almost all of the lakes in Africa for which there are records to have high P-loading rates at the same time? Modern freshwater lakes in Africa show a range of $\mathrm{Si}: \mathrm{P}$ ratios, and therefore a range on P-loading rates (Kilham et al., 1986). What made the situation different 9500 years ago? What mechanisms were operating to result in these apparently high rates of phosphorus loading to the epilimnia of all of the lakes that had high lake-levels and therefore deep mixed layers at that time? We would like to propose a series of hypotheses to explain the distribution of Stephanodiscus during the Holocene:

(1) The Si:P ratio in rivers changes very little with increasing discharge.

(2) In-lake processes dominate over catchment processes in regulating silicon and phosphorus loading rates to the epilimnia of tropical lakes.

(2a) There is a positive relationship between lake depth and increased internal P-loading in the epilimnion.

(2b) There is a positive relationship between depth of the mixed layer and phosphorus regeneration rates.

(2c) Meromictic lakes with sulphate reducing conditions in the hypolimnion often have lower $\mathrm{Si}: \mathrm{P}$ ratios in the epilimnion. This depends on the strength of the meromixis and the depth of the mixed layer.

(2d) Small, shallow lakes tend to have high Si:P ratios.

(2e) Surrounding papyrus vegetation (and other macrophytes) reduces P-loading to small lakes, either by direct uptake and storage or by packaging the phosphorus in large particulates that are more easily buried. 


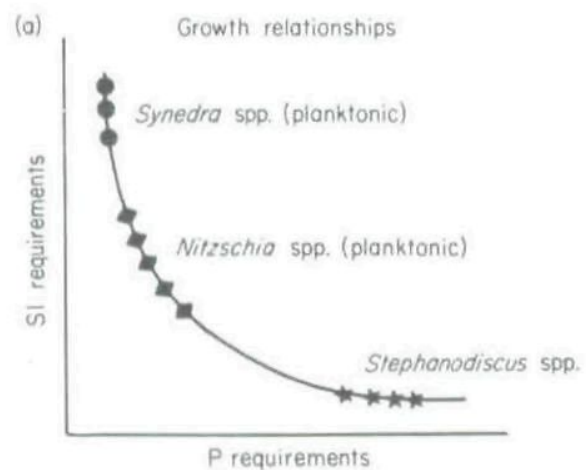

(b)

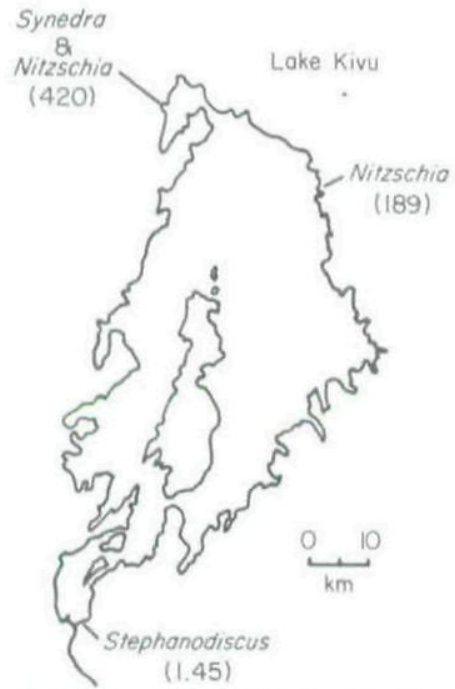

FIG. 2. Resource relationships among Africa planktonic diatoms. (a) Hypothesized growth relationships of euplanktonic diatoms that are commonly dominant in African freshwater lakes. Growth relationships are based on physiological investigations of similar diatoms from the temperate zone and distributional data for African diatoms. Species of Synedra out compete other planktonic diatoms at high Si:P ratios while species of Stephanodiscus are more competitive at low $\mathrm{Si}: \mathrm{P}$ ratios, Nitzschia species (with the exception of $N$. fonticola Grun., see Kilham et al., 1986) are competitive at intermediate Si:P ratios. Each point on the tradeoff curve can be defined by the equilibrium resource values for each species and each resource (Tilman, Kilham \& Kilham, 1982: Table 3 and Fig. 4) (based on Kilham et al., 1986). (b) Predominant diatom genera in the surface sediments of three distinct regions of Lake Kivu in relation to relevant Si:P ratios (in parentheses). For Kabuno Bay (top) the Si:P ratio of the submixing zone (the region directly below the mixed layer from which nutrients diffuse) is given. In the Northern Basin of Lake Kivu (right) nutrients are also supplied in part from the submixing zone. The Bakavu Basin (bottom) is less deep and generally well mixed. In this case concentration data for ambient nutrients were used. Data are from Degens \& Kulbicki (1973), Degens et al. (1973) and Hecky (unpubl.).

\section{Hypothesis 1}

The hypothesis that the Si:P ratios change very little with increasing discharge is supported on a global basis by Edwards \& Liss (1973) and for Africa by the work of Lesack, Hecky \& Melack (1984) on the Gambia River (Fig. 3). During the pluvial period in Africa precipitation may have been doubled (Grove, 1984). Increased precipitation probably increased the external loading of $\mathrm{Si}$ and $\mathrm{P}$ from rivers and it certainly contributed to the high lake-levels. Unlike most other elements (see Fig. 3, conductivity curve), silicon and phosphorous initially increase with increased discharge rates, and then change little above $200 \mathrm{~m}^{3} \mathrm{~s}^{-1}$. It is only when the river is acting like a lake (low discharge rates) that the dissolved concentrations of $\mathrm{Si}: \mathrm{P}$ are reduced, primarily owing to uptake and sedimentation by organisms. Otherwise, the ratio of Si:P remains remarkably constant with discharge. This would be an important argument for understanding the relative importance of catchment and in-lake processes during the period $10,000-8000$ years
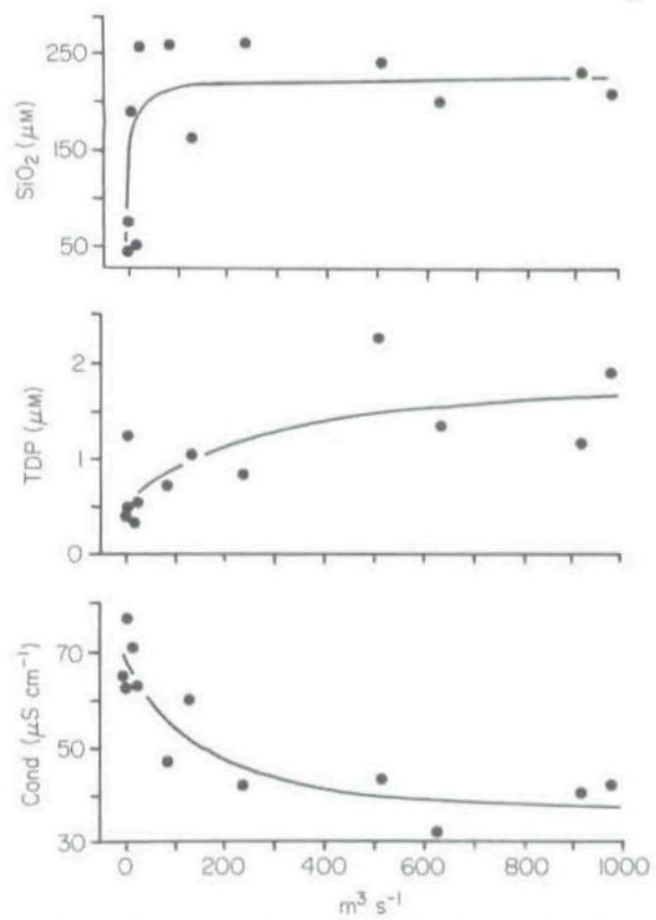

FIG. 3. Plots of silica, total dissolved phosphorus (TDP) and conductivity (Cond) versus Gambia River discharge. (Redrawn and modified from Lesack et al., 1984.) 
BP when mean annual rainfall was much higher than today's levels (Grove, 1984). These observations indicate that changes in the $\mathrm{Si}: \mathrm{P}$ supply ratios that determined the plankton diatom species composition of the pluvial lakes of Africa probably originated within the lake basins themselves and not in their catchments.

We are proposing that the additional precipitation increased the absolute amounts of both elements being loaded into the lakes, but did not change the Si:P ratio. The absolute amounts of $\mathrm{Si}$ and $\mathrm{P}$ producing a particular ratio can, of course, vary greatly leading to a complex relationship between the ratios and total biomass or productivity in a particular lake. However, the diatoms appear to be closely associated with a particular ratio and not with the absolute amounts of Si or P. In Lake Victoria, the absolute numbers of diatom frustules were highest about 9000 years BP (Stager, 1984a). Stephanodiscus has remained a dominant species in the sediment record although there has been a steady decrease in absolute abundance of total diatoms since $c$. 5000 years BP.

There are few data for other river systems in Africa (Table 2), but in general they have relatively low Si:P dissolved ratios $(<100$; Haberyan \& Hecky, 1987). The only stream samples that had higher Si:P ratios were ones dominated by bogs and swamps (see Hypothesis $2 \mathrm{e}$ below). It seems likely to us that in general the influent $\mathrm{Si}: \mathrm{P}$ ratios of large rivers entering lakes will be in the narrow range of $\mathrm{Si}: \mathrm{P}=30-100$. This range is also the one found in the deep, anoxic botton waters of the African rift valley lakes (Haberyan \& Hecky, 1987), and may represent a long-term mean in these ancient lakes.

\section{Hypothesis 2}

The hypothesis that in-lake processes dominate over catchment processes in regulating silicon and phosphorus loading to the epilimnia of lakes follows naturally if one accepts the argument given above that changes in discharge rates of rivers did not change Si:P ratios being loaded into lakes. We are then left with the problem of explaining why large, deep lakes in the tropics should have low Si:P loading ratios in their mixed layers. During the pluvial period from about 10,000 to $c .5000$ years BP, almost all the lakes in intertropical Africa from which there are diatom sediment records were apparently at their maximum lake-level, areas and mixed depths (Fig. 1).

Lake Albert has been at approximately its present lake-level essentially continuously since 12,500 years BP and has been dominated by Stephanodiscus for that entire period (Harvey, 1976). The lake is usually well mixed, and therefore generally oxygenated to the bottom $(58 \mathrm{~m})$. The same thing is essentially true for Lake Victoria (Kendall, 1969; Stager, 1984a) which is the lacustrine headwaters for the Nile River which flows through the northern end of Lake Albert.

If we accept the suggestion that tropical lakes are limnologically similar to temperate lakes during summer stratification (Kalff \& Watson, 1986) then temperate lakes can serve as analogues of the lakes of Africa on a year round basis. Analogues are required because the nutrient dynamics of most tropical lakes are unknown. The biogeochemical factors governing the cycling of silicon and phosphorus are better understood in temperate lakes (e.g.

TABLE 2. Molar ratios of dissolved silicon to soluble reactive phosphate in eight groups of streams and rivers in Uganda and eastern Zaire. Vegetation type and geology are given for each group. The Precambrian crystalline rocks in this region of Africa are predominantly gneiss, granite and schist. Si:P ratios were calculated for individual water analyses reported in Viner, 1975 (after Haberyan \& Hecky, 1987).

\begin{tabular}{lllcc}
\hline & & & \multicolumn{2}{l}{ Si:P } \\
\cline { 4 - 4 } Location & Vegetation & Geology & Range & Mean \\
\hline Karamoja & Steppe & Volcanic & $4.5-101$ & 49 \\
Semliki River & Savanna/Forest & Volcanic & $44.8-62.5$ & 52 \\
Mount Elgon & Moist Savanna & Crystalline & $53.0-97.7$ & 71 \\
Ruwenzori (West) & Forest/Savanna & Volcanic & $18.7-107$ & 81 \\
Kigezi & Rain Forest & Crystalline & $99.9-123$ & 99 \\
Ituri Forest & Bogs/Forest & Crystalline & $47.8-1510$ & 100 \\
Ruwenzori (East) & Papyrus Swamps & Crystalline & $123.0-1680$ & 210 \\
Central Plateau & & & 500 \\
\hline
\end{tabular}


Stauffer, 1986). Conley, Quigley \& Schelske (1988) have calculated for Lake Michigan (U.S.A.) that the turnover time of $\mathrm{Si}$ is low $(0.8$ year $\left.^{-1}\right)$ relative to the turnover of $\mathrm{P}(>8.8$ year $\left.^{-1}\right)$. They suggest that small enrichments in $\mathrm{P}$ may cause considerable depletion in $\mathrm{Si}$ as a consequence of increased diatom production and sedimentation, lending support to the 'silica demand hypothesis' (Kilham, 1971). This suggests that the availability of $\mathrm{Si}$ in the epilimnion is controlled largely by the biogeochemistry of P. It is therefore useful to review P-cycling in several lakes. A detailed ecological model of P-cycling in Lake Ontario (North America; Scavia, 1979) during stratification showed that $P$ originated from the following processess or sources: phytoplankton excretion ( $32.8 \%)$, zooplankton excretion $(37.5 \%)$, detritus decay $(17 \%)$, external load $(3.2 \%)$ and hypolimnetic load $(9.5 \%)$. In Rotsee and Horw Bay (Lake Lucerne, Switzerland), Bloesch, Stadelmann \& Bührer (1977) determined that epilimnetic $\mathrm{P}$-cycling supplied $55-85 \%$ of the $\mathrm{P}$ required to support primary production. P-cycling in tropical lakes has rarely been investigated (e.g. Anonymous, 1988).

Because there are essentially no data available on biogeochemical cycling of $\mathrm{P}$ and $\mathrm{Si}$ in African lakes, we are proposing a set of hypotheses that are at least consistent with observations of Si:P ratios in modern African lakes. The first of these (Hypothesis 2a) is that there is a positive relationship between lake depth and increased $\mathrm{P}$-loading to the epilimnion. This may be the result of intense physical mixing in large lakes owing to the increased fetch available for transferring wind energy to the lake (Beadle, 1981). This could cause large quantities of new $P$ to be transferred from below the mixed layer. Another factor is the hydrological budget of large lakes which is more dominated by rainfall and evaporation than by river inflow/outflow. Rainfall, with negligible Si concentrations, can dominate the external nutrient input to large African lakes with long water residence times (Hecky, pers. comm.).

African lakes that are $50 \mathrm{~m}$ or more deep are very productive and today have Stephanodiscus species as prominent members of the phytoplankton community (e.g. Lakes Albert, Tanganyika and Malawi: Kilham et al., 1986, Hecky \& Kling, 1987; Lake Victoria: Stager, 1984a). Lakes that are today shallow (Lake Naivasha) or exceptional owing to chemical meromixis (Lake Kivu) are dominated by other species of planktonic diatoms (Kilham et al., 1986). We believe increased $\mathrm{P}$ loading in deep lakes relative to shallow lakes explains part of the dichotomy.

This relationship between depth and mixed layer loading is probably complicated by the relative regeneration rates of silicon and phosphorus. Hypothesis $2 \mathrm{~b}$ indicates that there is a positive relationship between depth of the mixed layer and the rate of P-regeneration. In Lake Ontario, c. $87 \%$ of the P-load to the stratified epilimnion in the summer was due to regeneration processes taking place in that layer (Scavia, 1979). Regeneration processes are probably much more rapid in tropical lakes (owing to high temperatures) because increased mixed layer depth allows for greater turnover of the phosphorus pool and enzymatic reactions regenerating $\mathrm{P}$ are strongly related to temperature (Chròst \& Overbeck, 1987). If both sedimentation and dissolution processes were important for silicon regeneration, there would be increased epilimnetic Si-regeneration in deeper water columns, which might lead to slightly higher Si:P ratios in tropical lakes with very deep $(>100 \mathrm{~m})$ mixed layers (Malawi and Tanganyika) because a smaller fraction of the $\mathrm{Si}$ would be lost to permanent sedimentation. But, offsetting increases in $\mathrm{P}$ regeneration might also occur.

Hypothesis 2c states that meromictic lakes that reduce sulphate (and nitrate) in the hypolimnion often have low Si:P ratios in the epilimnion, but variations can occur depending in part on the strength of the meromixis and the depth of the mixed layer. Meromictic lakes can be characterized as being very selective in the removal of nutrients. In general, lakes that are meromictic and have reduced monimolimnia tend to have lower epilimnetic Si:P ratios probably because of increased loading of $\mathrm{P}$ from the reduced environments. Lakes that have large changes in the mixing regime during the year or the possibility of large internal waves (Lakes Tanganyika and Malawi: Coulter, 1988; Eccles, 1974) would have stronger gradients of nutrients from below than lakes that have very strong chemical meromixis (Lake Kivu: Degens et al., 1973). Haberyan \& Hecky (1987) have explained the higher epilimnetic Si:P loading ratios in Lake Kivu as being caused by the short 
circuiting of upwardly transported $\mathrm{P}$ by bacterial consumption at the oxic-anoxic interface. Phosphorus is retained by the bacterial plate, but $\mathrm{Si}$ goes through. The deep waters of the lake actually have lower $\mathrm{Si}: \mathrm{P}$ ratios than the surface waters.

Another potential complicating factor is the availability of iron. In cases where sulphide dominates ferrous iron in anaerobic hypolimnia, phosphate can migrate upwards across the interface into the oxic region unaccompanied by iron and thus remain in solution (Stauffer, 1986). Larger lakes probably have lower concentrations of iron available relative to smaller lakes (Talling \& Talling, 1965).

The silicon fluxes in epilimnia are tightly coupled to the relative loading of phosphorus. As $\mathrm{P}$ concentrations increase, 'Si-demand' by the diatoms also increases. In Lake Albert, riverine input of $\mathrm{Si}$ is somewhat lower because the lake receives its inflows from Lakes Edward and Victoria/Kioga which are sinks for $\mathrm{Si}$ (Table 2; Viner, 1975). The lake has sufficient P-loading to create a very high $\mathrm{Si}$-demand and very low $\mathrm{Si}$ :P ratios (c. 1.4). The southern arm of Lake Kivu represents a similar situation to Lake Albert (Fig. 2b). In both cases the permanent sedimentation of diatoms is greater than the input of Si. In Lakes Tanganyika and Malawi, the $\mathrm{Si}: \mathrm{P}$ ratios are somewhat higher (Kilham et al., 1986; Haberyan \& Hecky, 1987; Kilham, 1989), probably because the loading of Si to the epilimnion and the longer water column available for regeneration processes more effectively balance the losses to permanent sedimentation. These lakes also have very long water residence times (Fig. 4). In the main part of Lake Kivu, the chemical meromixis makes the lake exceptional even though it has reducing conditions. The nutrient transfer from below is selective, owing to the bacterial plate. It has a mixing depth of $<65$ m (Damas, 1937; Degens et al., 1973). The isolated Kabuno Bay has an even lower mixing depth (<20 m; Degens \& Kulbicki, 1973), greater stability, and a bacterial plate and consequently has higher Si:P ratios in the epilim-

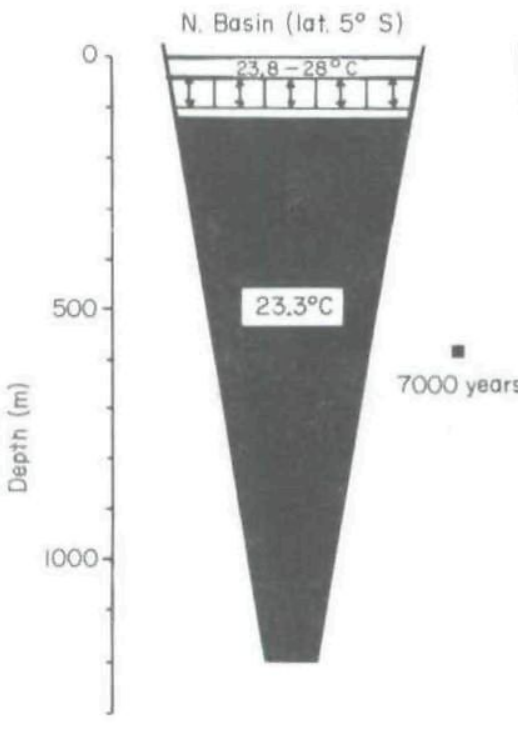

S. Basin (lat $7^{\circ} \mathrm{S}$ )
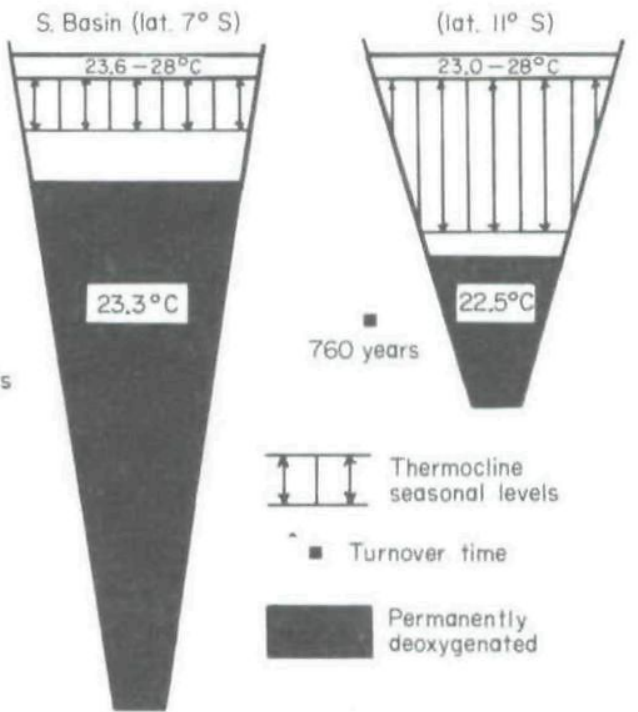

Lake Victorid

(lat. $1^{\circ} \mathrm{S}$ )

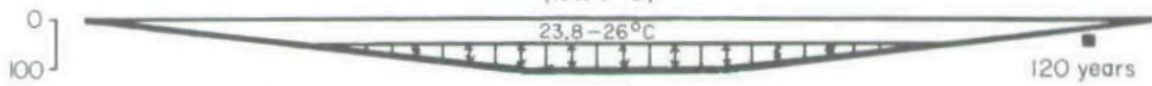

FIG. 4. Transverse sections showing seasonal mixing patterns in some African Great Lakes. Turnover times (lake volume divided by water outflow) were calculated from data in Hecky \& Degens, 1973; Serruya \& Pollingher, 1983; and Hecky \& Kling, 1987. (Redrawn and modified from Beauchamp, 1964.) 
nion. In these cases most of the sedimented $\mathrm{P}$ is trapped in the bottom waters (Haberyan \& Hecky, 1987).

Hypothesis 2d is that small, shallow lakes tend to have high $\mathrm{Si}$ :P ratios (Fig. 5). One reason is that the hydraulic residence times are much shorter in these lakes, and therefore they tend to be more influenced by catchment processes which would supply $\mathrm{Si}: \mathrm{P}$ ratios in the range of $30-100$ or so. The short water column does not allow very much time for nutrient regeneration and reduced conditions are generally confined to the sediments. Complexation of $\mathrm{P}$ with $\mathrm{Fe}$ and other metals coming from the drainage basin may also allow for permanent removal of phosphorus. On the other hand, the epilimnetic sediments are likely to be a major source of $\mathrm{Si}$. Studies in temperate lakes (Rippey, 1983) show that a major part of the $\mathrm{Si}$ loading is from regeneration in the sediments and that the process is highly temperature dependent. The relationship between sediment area to epilimnetic volume (Fee, 1979) is probably an important aspect of the Si cycle in small lakes. In the case of volcanic crater lakes (Fig. 5), the protected aspect of most of these lakes produces little variation in mixing depth and therefore strong meromixis is a common feature (Melack, 1978). The permanent sedimentation of algae and associated bacteria can reduce $\mathrm{P}$-availability in the epilimnion (Gächter \& Mares, 1985). As in
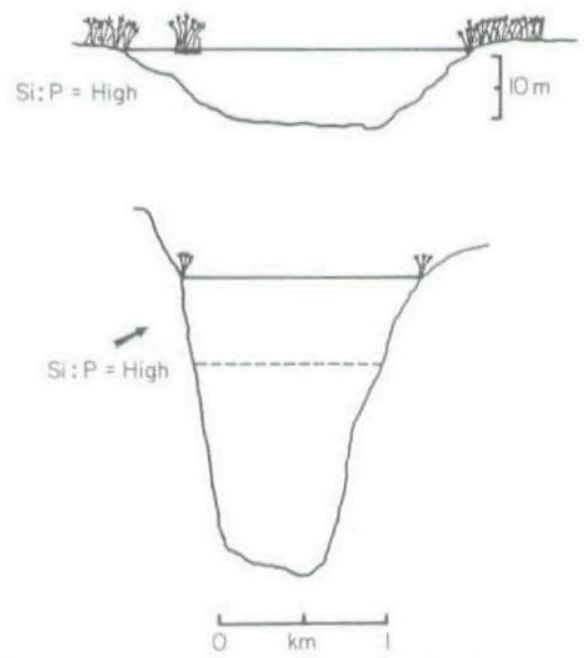

FIG. 5. Freshwater lakes with high Si:P ratios are commonly relatively shallow and holomictic or deep and meromictic.
Lake Kivu, bacterial plates at the oxic/anoxic interface may be present which stop the upward transport of P (Haberyan \& Hecky, 1987). All of these processes tend to increase the epilimnetic $\mathrm{Si}: \mathrm{P}$ ratios.

An additional process can apparently remove phosphorus from small lakes. Hypothesis $2 \mathrm{e}$ indicates that surrounding vegetation (usually papyrus) reduces P-loading either by direct uptake and storage (Gaudet, 1977; Chale, 1987) or by packaging the phosphorus in large particulates that are more easily buried. HowardWilliams \& Gaudet (1985) concluded that papyrus swamps have a large capacity to take up nutrient elements such as $\mathrm{N}, \mathrm{P}$ and $\mathrm{S}$ from inflowing waters, but caution that there are no complete nutrient budgets for any tropical swamp so regenerative processes within the swamp could conceivably make them net sources rather than sinks for some elements.

\section{Conclusions}

In an attempt to explain the widespread dominance of Stephanodiscus species across intertropical Africa c. 9500 years BP, we have suggested a series of processes that could produce low Si:P ratios in the epilimnia of these lakes. We have argued that the lakes for which there are records were all at their maximum lake-level which positively influenced a number of processes. Large basins provide for long residence times and greater opportunities for increased mixing depths owing to wind action (Kling, 1988). Large fetch contributes to greater inputs from the hypolimnion. Also, increased depth allows for the possibility of an anoxic hypolimnion with reducing conditions. Larger lakes apparently have lower amounts of metals available for complexation with $\mathrm{P}$, which again contributes to the possibility of increased P-loading from hypolimnetic waters.

A major hypothesis we have presented is that there is greater aerobic P-regeneration in deeper water columns. The larger number of times $\mathrm{P}$ can recycle within the mixed layer, the greater will be the $\mathrm{Si}$-demand, because $\mathrm{P}$ cycles much faster than $\mathrm{Si}$. The result is a low $\mathrm{Si}: \mathrm{P}$ ratio.

All of the arguments we have presented require testing. We are suggesting that tropical lakes have many processes in common with tem- 
perate lakes during the summer. However, the conclusions we reach from this are opposite to the 'conventional wisdom' concerning nutrient cycling in temperate lakes. In the temperate zone, larger, deeper lakes tend to be more oligotrophic than smaller lakes; in the tropics, we are suggesting a different pattern. Perhaps in the case of 'endless summer', regeneration rates are greater than removal rates at least where epilimnetic mixing depths exceed c. $50 \mathrm{~m}$. What we are really suggesting is that biological control of the elemental cycles dominates in tropical lakes and that physical mixing supplies new inputs that are used for increased production and largely retained in the epilimnion by the action of organisms. Temperature is essentially constant and high, allowing rapid recycling by heterotrophic organisms. Recycling of the nutrient elements in the mixed layers of the lakes results in a very high probability of retaining the sedimenting nutrients in the epilimnion. Larger, deeper lakes apparently enhance this retention probability for $\mathrm{P}$ to a much greater degree than $\mathrm{Si}$, giving lower $\mathrm{Si}: \mathrm{P}$ ratios and increasing the productivity. In contrast, nutrient cycles in temperate lakes are dominated by physical processes governed by the thermal regime and light limitation. The fact that physical processes dominate over biological processes for a large part of the year may be the major reason for the wellknown relationship (Fee, 1979) between primary production and the ratio of epilimnion sediment area to epilimnion volume in temperate systems. This limnological 'rule' has been useful for management purposes, but we are suggesting that this would not be the case for tropical lakes. There may be some fundamental mechanisms concerning nutrient regeneration processes that can be more easily discerned through comparative studies of tropical lakes.

\section{Acknowledgments}

We thank R. J. Chròst, J. B. Cotner, E. Fee, R. W. Gensemer, R. E. Hecky, R. L. Keisling, U. Sommer and R. G. Wetzel for critical review of the manuscript. This work was carried out, in part, while S.S.K. was a Max-Planck-Society scholar and P.K. held an Alexander von Humboldt Award (U.S. Senior) at the Max-PlanckInstitute für Limnologie in Plön, West Germany.
Peter Kilham tragically died on 20 March, 1989, of a haemorrhage, in Kisumu, Kenya, while working as part of a research team on Lake Victoria.

\section{References}

Anonymous (1988) Sediment phosphorus group: Working group summaries and proposals for future research. Archiv für Hydrobiologie Ergebenis für Limnologie, 30, 83-112.

Beadle L.C. (1981) The Inland Waters of Tropical Africa, 2nd edn. Longman, London.

Beauchamp R.S.A. (1964) The rift valley lakes of Africa. Verhandlungen der Internationale Vereinigung für Theoretische und Angewandte Limnologie, 15, 91-99.

Bloesch J., Stadelmann P. \& Bührer H. (1977) Primary productivity, mineralization, and sedimentation in the euphotic zone of two Swiss lakes. Limnology and Oceanography, 22, 511-526.

Carney H.J., Richerson P.J., Goldman C.R. \& Roberts R.C. (1988) Seasonal phytoplankton demographic processes and experiments in interspecific competition. Ecology, 69, 664-678.

Chale F.M.M. (1987) Plant biomass and nutrient levels of a tropical macrophyte (Cyperus papyrus $\mathrm{L}$.) receiving domestic wastewater. Hydrobiological Bulletin, 21, 167-170.

Chròst R.J. \& Overbeck J. (1987) Kinetics of alkaline phosphatase activity and phosphorus availability for phytoplankton and bacterioplankton in Lake Plussee (north German eutrophic lake). Microbial Ecology, 13, 229-248.

Conley D.J., Quigley M.A. \& Schelske C.L. (1988) Silica and phosphorus flux from sediments: Importance of internal recycling in Lake Michigan. Canadian Journal of Fisheries and Aquatic Sciences, 45, 1030-1035.

Coulter G.W. (1988) Seasonal hydrodynamic cycles in Lake Tanganyika. Verhandlungen der Internationale Vereinigung für Theoretische und Angewandte Limnologie, 23, 86-89.

Damas H. (1937) Recherches hydrobiologiques dans les lacs Kivu, Edouard et Ndalaga. Exploration du Parc National Albert, Mission H. Damas (19351936), Fascicule I.

Degens E.T. \& Kulbicki G. (1973) Data file on metal distribution in East African rift sediments. Woods Hole Oceanographic Institution, Technical Report, WHOI-73-17.

Degens E.T., von Herzen R.P., Wong H.-K., Deuser W.G. \& Jannasch H.W. (1973) Lake Kivu: structure, chemistry and biology of an East African Rift Lake. Geologischen Rundschau, 62, 245-277.

Eccles D.H. (1974) An outline of the physical limnology of Lake Malawi (Lake Nyasa), Limnology and Oceanography, 19, 730-742.

Edwards A.M.C. \& Liss P.S. (1973) Evidence for buffering of dissolved silicon in fresh waters. Nature, 243, 341-342.

Fee E.J. (1979) A relation between lake morphometry and primary productivity and its use in interpreting 
whole-lake eutrophication experiments. Limnology and Oceanography, 24, 401-416.

Gächter R. \& Mares A. (1985) Does settling seston release soluble reactive phosphorus in the hypolimnion of lakes? Limnology and Oceanography, 30, 364-371.

Gasse F. (1977) Evolution of Lake Abhé (Ethiopia and TFAI), from 70,000 b.p. Nature, 265, 42-45.

Gasse F. (1980) Late Quaternary changes in lake-level and diatom assemblages on the south-eastern margin of the Sahara. Palaeoecology of Africa, 12, 333-350.

Gasse F. \& Descourtieux C. (1979) Diatomes et volution de trois milieux éthiopiens d'altitude différente, au cours du Quaternaire supérieur. Palaeoecolaogy of Africa, 11, 117-134.

Gasse F., Rognon P. \& Street F.A. (1980) Quaternary history of the Afar and Ethiopian Rift Lakes. The Sahara and the Nile (Eds M. A. J. Williams and H. Faure), pp. 361-400. A. A. Balkema, Rotterdam.

Gaudet J.J. (1977) Uptake, accumulation, and loss of nutrients by papyrus in tropical swamps. Ecology, 58, 415-422.

Grove, A.T. (1984) Changing climate, changing biomass and changing atmospheric $\mathrm{CO}_{2}$. Progress in Biometeorology, 3, 5-10.

Haberyan K.A. (1987) Fossil diatoms and the paleolimnology of Lake Rukwa, Tanzania. Freshwater Biology, 11, 429-436.

Haberyan K.A. \& Hecky R.E. (1987) The late Pleistocene and Holocene stratigraphy and paleolimnology of lakes Kivu and Tanganyika. Palaeogeography Palaeoclimatology Palaeoecology, 61, 169-197.

Hamilton A.C. (1982) Environmental History of East Africa. Academic Press, London.

Harvey T.J. (1976) The paleolimnology of Lake Mobuto Sese Seko, Uganda-Zaire: the last 28,000 years. Ph.D. thesis, Duke University, Durham.

Hecky R.E. (1978) The Kivu-Tanganyika basin: the last 14,000 years. Polskie Archiwum Hydrobiologii, 25, 159-165.

Hecky R.E. \& Degens E.T. (1973) Late PleistoceneHolocene chemical stratigraphy and paleolimnology of the rift valley lakes of Central Africa. Woods Hole Oceanographic Institution, Technical Report, WHOI-73-28.

Hecky R.E. \& Kling H.J. (1987) Phytoplankton ecology of the great lakes in the rift valley of central Africa. Ergebnisse der Limnologie, 25, 197-228.

Holdship S.A. (1976) The paleolimnology of Lake Manyara, Tanzania. Ph.D. thesis, Duke University, Durham.

Howard-Williams C. \& Gaudet J.J. (1985) The structure and functioning of African swamps. The Ecology and Management of African Wetland Vegetation (Ed. P. Denny), pp. 153-175. Dr W. Junk, Dordrecht.

Huitfeldt-Kaas H. (1898) Plankton in norwegischen Binnenseen. Biologische Centralblatt, 18, 625636.

Kalff J. \& Watson S. (1986) Phytoplankton and its dynamics in two tropical lakes: a tropical and temperate zone comparison. Hydrobiologia, 138, 161176.
Kendall R.L. (1969) An ecological history of the Lake Victoria basin. Ecological Monographs, 39, 121179.

Kilham P. (1971) A hypothesis concerning silica and the freshwater planktonic diatoms. Limnology and Oceanography, 16, 10-18.

Kilham P., Kilham S.S. \& Hecky R.E. (1986) Hypothesized resource relationships among African planktonic diatoms. Limnology and Oceanography, 31, 1169-1181.

Kilham S.S. (1984) Silicon and phosphorus growth kinetics and competitive interactions between Stephanodiscus minutus and Synedra sp. Verhandlungen der Internationale Vereinigung für Theoretische und Angewandte Limnologie, 22, 435-439.

Kilham S.S. (1989) Relationships of phytoplankton and nutrients to stoichiometric measures. In: Ecological Structure and Function in Large Lakes (Eds M. M. Tilzer and C. Serruya). Science Tech Publishers, Madison, Wisconsin.

Kling G.W. (1988) Comparative transparency, depth of mixing, and stability of stratification of lakes of Cameroon, West Africa. Limnology and Oceanography, 33, 27-40.

Lesack L.F.W., Hecky R.E. \& Melack J.M. (1984) Transport of carbon, nitrogen, phosphorus, and major solutes in the Gambia River, West Africa. Limnology and Oceanography, 29, 816-830.

Melack J.M. (1978) Morphometric, physical and chemical features of the volcanic crater lakes of western Uganda. Archiv für Hydrobiologie, 84, 430-453.

Owen R.B., Barthelme J.W., Renaut R.W. \& Vincens A. (1982) Palaeolimnology and archaeology of Holocene deposits north-east of Lake Turkana, Kenya. Nature, 298, 523-529.

Richardson J.L. \& Dussinger R.A. (1986) Paleolimnology of mid-elevation lakes in the Kenya Rift Valley. Hydrobiologia, 143, 167-174.

Richardson J.L. \& Richardson A.E. (1972) History of an African rift lake and its climatic implications. Ecological Monographs, 42, 499-534.

Rippey B. (1983) A laboratory study of the silicon release process from a lake sediment (Lough Neagh, Northern Ireland). Archiv für Hydrobiologie, 96, 417-433.

Scavia D. (1979) Examination of phosphorus cycling and control of phytoplankton dynamics in Lake Ontario with an ecological model. Canadian Journal of Fisheries and Aquatic Sciences, 36, 13361346.

Serruya C. \& Pollingher U. (1983) Lakes of the Warm Belt. Cambridge University Press.

Servant M. \& Servant-Vildary S. (1980) L'environnement quaternaire du bassin du Tchad. The Sahara and the Nile (Eds M. A. J. Williams and H. Faure), pp. 133-162. A. A. Balkema, Rotterdam.

Servant M. \& Servant S. (1983) Paleolimnology of an upper quaternary endorheic lake in Chad Basin. Lake Chad: ecology and productivity of a shallow tropical ecosystem (Eds J.-P. Carmouze, J. R. Durand and C. Lèvêque), pp. 11-26. Dr W. Junk Publishers, The Hague.

Stager J.C. (1984a) The diatom record of Lake Vic- 
toria (East Africa): the last 17,000 years. Proceedings of the Seventh International Diatom Symposium, Philadelphia (Ed. D. G. Mann), pp. 455-476. Otto Koeltz Science Publishers, Koenigstein.

Stager J.C. (1984b) Environmental changes at Lake Cheshi, Zambia since 40,000 years B.P. with additional information from Lake Victoria, East Africa. Ph.D. thesis, Duke University, Durham.

Stauffer R.E. (1986) Linkage between the phosphorus and silica cycles in Lake Mendota, Wisconsin. Water Research, 20, 597-609.

Talling J.F. \& Talling I.B. (1965) The chemical com- position of African lake waters. Internationale Revue der Gesamten Hydrobiologie, 50, 421-463.

Tilman D., Kilham S.S. \& Kilham P. (1982) Phytoplankton community ecology: The role of limiting nutrients. Annual Review of Ecology and Systematics, 13, 349-372.

Viner A.B. (1975) The supply of minerals to tropical rivers and lakes (Uganda). Coupling of Land and Water Systems (Ed. A. D. Hasler), pp. 227-261. Springer, New York.

(Manuscript accepted 24 July 1989) 
This document is a scanned copy of a printed document. No warranty is given about the accuracy of the copy. Users should refer to the original published version of the material. 